\title{
AGE-RELATED DECLINE IN PROTEIN SYNTHESIS IN THE RAT PAROTID GLAND
}

\author{
S. K.KIM*, P. A. Weinhold†, S. S. HANキ and D. J. WAGNER \\ Research Service, V.A. Medical Center*† Ann Arbor, MI 48105 and the University of Michigan \\ Medical School, ${ }^{*} \dagger \neq \S$ Ann Arbor, Michigan, U.S.A.
}

(Received 10 September 1979)

\section{INTRODUCTION}

PREVIOUS studies have reported that age-related changes occur in cellular protein synthesis in many types of tissues. Although it has been reported that protein synthesis increases with aging, as in the synthesis of liver albumin (Beauchene et al., 1970; Chen et al., 1973), many other studies have indicated a reduction in protein synthesis. A reduction in protein synthesis has been demonstrated in many animal tissues, such as muscle (Brever et al., 1964; Srivastava, 1969), brain (Murthy and Rapport, 1965; Johnson and Belytschko, 1969; Johnson, 1968), liver (Mainwaring, 1968, 1969; Hrachovec, 1969; Kurtz, 1975; Layman et al., 1976), lens (Klethi, 1976) and testis (Liu et al., 1978).

If the decrease in protein synthesis is a general phenomenon in aging, the effect of such a decrease is expected to be very pronounced in exocrine glands which synthesize a large quantity of proteins for export, such as salivary glands and the pancreas. However, there is no information available regarding the changes in protein synthesis with aging in these glands.

The present study was undertaken to determine whether age-related changes in protein synthesis occur in parotid salivary glands. The parotid gland provides an excellent system for this kind of study, because the gland produces purely serous secretion, a large proportion of which is proteins consisting primarily of $\alpha$-amylase (Schramm, 1968). This study compares the differences in the incorporation of ${ }^{3} \mathrm{H}$-leucine into proteins and the conversion of $\left[\mathrm{U}-{ }^{4} \mathrm{C}\right]$-glucose to $\mathrm{CO}_{2}$, total lipids and proteins by parotid gland slices from 2-, 12-, 18-, 24- and 30-month-old rats.

\section{MATERIALS AND METHODS}

\begin{abstract}
Animals
Male Sprague-Dawley rats 2, 12, 18, 24 and 30 months old were used, and obtained from Charles River Breeding Laboratories in Wilmington, Massachusetts. Older rats (18 months and older) were obtained from the N.I.A. Aging Colony maintained at the above breeder. All rats were housed in an isolator upon arrival and allowed to acclimate for at least 3 days before beginning the experiments. Food was removed from these rats at about $3 \mathrm{p} . \mathrm{m}$. the day before the experiment and the rats were killed between 8 and 9 a.m. on the day of the experiments. After killing the rats by cervical dislocation, both glands were removed and placed in a dish of ice cold phosphate buffered saline (PBS) or in Minimum Essential Medium (MEM). The connective tissue, nerves and large ducts in the central region were removed from the glands. The glands were sliced with a Stadie-Riggs tissue slicer. Small pieces of gland from old rats were prepared for light microscopy to screen them for signs of any pathological changes.

\section{${ }^{3} \mathrm{H}$-leucine incorporation studies}

The tissue slices were placed in a Petri dish containing MEM which had been gassed with $95 \% \mathrm{O}_{2}$ and $5 \% \mathrm{CO}_{2}$ and kept on ice. After all the slices had been collected, they were divided into groups and each group was placed in a $25 \mathrm{ml}$ Erlenmeyer flask containing $5 \mathrm{ml}$ of MEM without leucine. The medium contained $3 \mu \mathrm{Ci} / \mathrm{ml}$ of L-(4,5- ${ }^{3} \mathrm{H}(\mathrm{N})$-leucine (sp. act. $47-52 \mathrm{Ci} / \mathrm{m}$-mole: New England Nuclear) and was supplemented with ' $\mathrm{H}$-leucine to a concentration of $0.1 \mathrm{mM}$. The flasks containing tissue slices and medium were continuously gassed and kept on ice for $10 \mathrm{~min}$. After this, the flasks were transferred to a water bath maintained at $37^{\circ} \mathrm{C}$
\end{abstract}


and agitated at about $70-90 \mathrm{c} / \mathrm{min}$ while maintaining the $95 \% 0_{2}-5 \% \mathrm{CO}$ atmosphere. After incubation, the tissues were filtered through miracloth, rinsed three times with PBS and homogenized in $2 \mathrm{ml}$ PBS. A known amount of the homogenate was removed for the determinations of total radioactivity. The remaining homogenate was precipitated with an equal amount of $0.6 \mathrm{~N}$ perchloric acid (PCA) and the precipitate was fractionated according to the methods described by Hinrichs et al. (1964) to extract the proteins and DNA. The supernatant was used to determine the ${ }^{3} \mathrm{H}$-leucine available in the PCA-soluble pool. DNA content was determined on hot PCA $(0.5 \mathrm{~N})$ extracts from the PCA precipitates by using the diphenylamine method of Burton (1956). Calf thymus DNA (Sigma) was used as the standard for DNA determination. The remaining pellet after DNA extraction was dissolved in NCS tissue solubilizer (Amersham). Radioactivity in the acid soluble fractions and in the dissolved pellets was counted in a Packard Scintillation Spectrometer. Counting rates were corrected for quenching and background with an external standard. Total leucine incorporated into proteins, calculated from the total radioactivity and the specific activity of ' $\mathrm{H}$-leucine in the medium, was expressed based on the DNA content of the gland.

\section{Glucose metabolism studies}

The gland slices were divided into samples of approximately $100 \mathrm{mg}$, and placed in $3 \mathrm{ml}$ of gassed $\left(95 \% \mathrm{O}_{2}\right.$, $5 \% \mathrm{CO}_{2}$ ) Krebs Ringer Bicarbonate (KRB) solution. The medium was supplemented with glucose to a final concentration of $5 \mathrm{mM}$ and contained $1 \mu \mathrm{Ci} / \mathrm{ml}\left[\mathrm{U}-{ }^{14} \mathrm{C}\right]-\mathrm{D}$-glucose. The flasks were flushed with $95 \% \mathrm{O}_{2}$, $5 \% \mathrm{CO}_{2}$ and stoppered tightly with a serum cap from which a plastic bucket, containing a piece of fluted filter paper, was suspended. The flasks were incubated at $37^{\circ} \mathrm{C}$ with shaking (about $70-90 \mathrm{c} / \mathrm{min}$ ). After $1 \mathrm{~h}$ of incubation, a syringe was used to add $1.1 \mathrm{ml}$ of $20 \%$ trichloroacetic acid (TCA) to the flask and $0.4 \mathrm{ml} \mathrm{NCS}$ tissue solubilizer (Amersham) to the bucket. The flasks were incubated another $1 \mathrm{~h}$ at $37^{\circ} \mathrm{C}$ with continuous shaking. After this time the tissue and solution were poured into a homogenizing vessel on ice. The flask was rinsed twice with $1.5 \mathrm{ml}$ cold saline. The rinses were added to the homogenizing vessels. The vessels were centrifuged at $2000 \mathrm{rev} / \mathrm{min}$ (Sorvall $\mathrm{RC}-3$ ) for $3 \mathrm{~min}$ to collect the slices. The plastic buckets with the NCS and filter paper were cut off and placed in scintillation vials which contained $10 \mathrm{ml}$ OCS (Amersham), and the amount of radioactivity was determined.

The lipid from the tissue slices was extracted and washed according to the Folch method (1957). The chloroform was evaporated with a stream of air and the lipid was dissolved in $1 \mathrm{ml} \mathrm{of} \mathrm{CHCl}_{3}$. Samples were removed and the amount of radioactivity was determined by liquid scintillation counting.

The pellet remaining after lipid extraction was suspended in $0.3 \mathrm{~N} \mathrm{PCA}$, and centrifuged. Pellets were extracted with hot PCA $(0.5 \mathrm{~N})$ and the supernatant was assayed for DNA accordir ; to Burton's method (1956). The pellet remaining after DNA extraction was solubilized in NCS tissue solubilizer and the amount of radioactivity in PCA-insoluble proteins was determined.

\section{Tissue preparations for microscopy}

Light microscopy. The glands were fixed rountinely in Bouin's fixative, embedded in paraffin, sectioned and stained with hematoxylin and eosin.

Radioautography. After incubation, the tissues were prepared for radioautography as described by Castle et al. (1972). The gland slices were fixed in $10 \%$ formaldehyde in $0.175 \mathrm{M}$ potassium phosphate buffer, pH 7.2 . The fixative was changed 6-7 times and further fixed overnight in the refrigerator. Specimens were postfixed in $1 \% \mathrm{OsO}_{4}$, dehydrated and embedded in Epon. Sections $1 \mu \mathrm{m}$ thick were cut and placed on microscope slides. The slides were dip coated with NTB2 emulsion (Kodak) diluted with distilled water in a dark room maintained at $21^{\circ} \mathrm{C}$ and $70 \%$ relative humidity. After $2-4$ days exposure in the refrigerator, the slides were developed in D-19 (Kodak) diluted 1:2 with water, fixed in Kodak fixer, rinsed, dried and stained briefly with $1 \%$ toluidine blue.

Electron microscopy. The glands were fixed by perfusing the animal through the heart with a mixture of $1 \%$ paraformaldehyde and $1.5 \%$ glutaraldehyde buffered with $0.1 \mathrm{M}$ sodium cacodylate to $\mathrm{pH} 7.4$. The glands were removed, sliced into smaller pieces and further fixed in the same fixative for $1 \mathrm{~h}$. The tissues were post-fixed in $\mathrm{OsO}_{4}$ and prepared for electron microscopy as previously described (Kim, 1976).

\section{RESULTS}

\section{Incorporation of ${ }^{3} \mathrm{H}$-leucine into proteins}

The incubation system used supports linear incorporation of ${ }^{3} \mathrm{H}$-leucine for $3 \mathrm{~h}$. Radioactivity is incorporated into PCA-insoluble proteins of the gland slices from young ( 2 months) and old ( 30 months) rats at a constant rate for $1 \mathrm{~h}$ (Fig. 1). Therefore, the gland slices from all age groups were routinely incubated with ${ }^{3} \mathrm{H}$-leucine for $30 \mathrm{~min}$ throughout this study. Electron microscopy of the gland slices incubated for $30 \mathrm{~min}$ also shows the well-preserved appearance of the secretory acinar cells. 


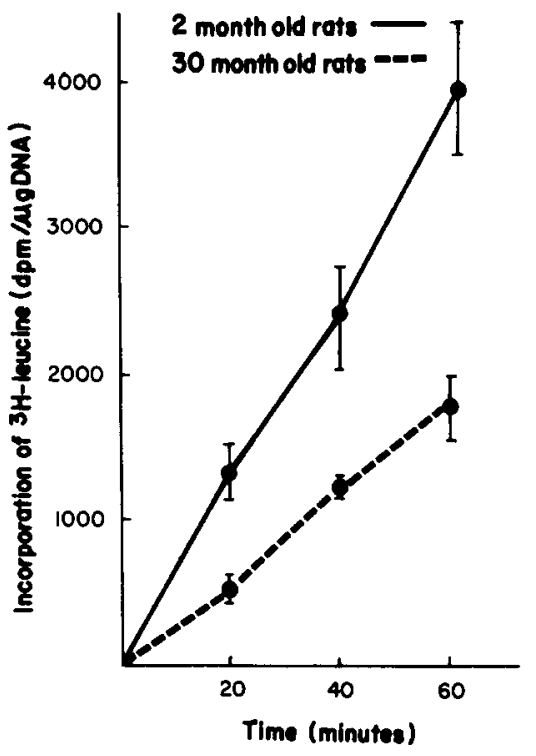

FIG. 1. Incorporation of ${ }^{3} \mathrm{H}$-leucine into perchloric acid insoluble protein. The radioactivity is incorporated at a constant rate for $1 \mathrm{~h}$ by the gland slices from both 2 -month and 30 -month-old rats.

Incorporation of ${ }^{3} \mathrm{H}$-leucine into proteins is highest in 2 -month-old rats and decreases progressively with increasing age (Table 1). The level of leucine incorporation is reduced by $79,71,51$ and $42 \%$ of the 2 -month level in 12-, 18-, 24- and 30-month-old rats, respectively. There is no significant difference in the amount of radioactivity in the acid soluble fractions of the glands from 2-, 12- and 24-month-old rats (Table 2). Thus, it appears that the free leucine pool remains fairly stable in different age groups.

TABLE 1. AGE-RELATED DIFFERENCES IN THE INCORPORATION OF LEUCINE INTO PROTEINS

\begin{tabular}{cc}
\hline Age (months) & nmole/mg DNA \pm S.E. \\
\hline 2 & $138.43 \pm 5.45^{*} \dagger \neq \S$ \\
12 & $109.77 \pm 6.88 \neq \S$ \\
18 & $97.77 \pm 4.68 \neq \S$ \\
24 & $71.62 \pm 4.13$ \\
30 & $58.08 \pm 5.61$ \\
\hline
\end{tabular}

\footnotetext{
* Value differs significantly from the 12 month value $(p \leqslant 0.05)$

$\dagger$ Value differs significantly from the 18 month value $(p \leqslant 0.05)$.

\$ Value differs significantly from the 24 month value $(p \leqslant 0.05)$.

$\S$ Value differs significantly from the 30 month value $(p \leqslant 0.05)$.
}

Metabolism of $\left[\mathrm{U}-{ }^{14} \mathrm{C}\right]-\mathrm{D}-\mathrm{glucose}$

The metabolism of $\left[\mathrm{U}-{ }^{14} \mathrm{C}\right]-\mathrm{D}$-glucose by the gland slices from different age groups was investigated to estimate the level of general cellular metabolism and to compare the incorporation of the label into total lipid and proteins (Table 3). The ability of the gland slices to oxidize $\left[\mathrm{U}-{ }^{14} \mathrm{C}\right]-\mathrm{D}$-glucose to ${ }^{14} \mathrm{CO}_{2}$ and to incorporate radioactivity into total 
TABLE 2. LEUCINE INCORPORATION INTO THE ACID SOLUBLE FRACTION

\begin{tabular}{cc}
$\begin{array}{c}\text { Age } \\
\text { (months) }\end{array}$ & $\begin{array}{c}\text { nmole/mg DNA } \\
\pm \text { S.E. }\end{array}$ \\
\hline 2 & $0.141 \pm 0.017$ \\
12 & $0.141 \pm 0.023$ \\
24 & $0.121 \pm 0.016$ \\
\hline
\end{tabular}

lipids is not reduced with increasing age. On the other hand, incorporation of radioactivity into proteins decreases with age. The level of radioactivity in PCA-insoluble proteins in the gland of 24-month-old rats is greatly reduced as compared with that in the gland of 2 -month-old rats, thus paralleling the decrease in ${ }^{3} \mathrm{H}$-leucine incorporation in rats of this age.

TABLE 3. COMPARISON OF GLUCOSE METABOLISM BY THE PAROTID GLAND SLICES

\begin{tabular}{|c|c|c|c|}
\hline $\begin{array}{c}\text { Age } \\
\text { (months) }\end{array}$ & \multicolumn{3}{|c|}{ nmole glucose $/ \mathrm{mg}$ DNA \pm S.E. } \\
\hline & $\mathrm{CO}_{2}$ & protein & lipid \\
\hline 2 & $253.87 \pm 14.36$ & $45.06 \pm 3.55$ & $27.70 \pm 1.20$ \\
\hline 18 & $287.77 \pm 15.19$ & $41.50 \pm 2.96$ & $26.05 \pm 0.94$ \\
\hline 24 & $312.58 \pm 21.24^{*}$ & $28.36 \pm 2.85^{*}, t$ & $25.13 \pm 1.98$ \\
\hline
\end{tabular}

*Differs significantly from 2 month value $(p \leq 0.05)$

${ }^{\dagger}$ Differs significantly from 18 month value $(p \leq 0.05)$

\section{Microscopic appearance of the gland}

Histologically, gland from rats of different ages appears similar except for the increase in the amount of fat in older rats. Portions of the gland shown in Fig. 2 and Fig. 3 illustrate the structure of young and old glands respectively. Both glands are organized into lobules which are separated from the adjacent ones by connective tissue. The lobules are made up of secretory acinar cells and ducts which are located in the central portion of each lobule. The amount of connective tissues or the proportion of ductal cells to secretory cells in rats of different ages does not appear to change. However, there is considerably more fat in the glands of older rats than in young ones. As can be seen in Fig. 3, the fat is mostly located at the periphery of the lobules in 30-month-old rats. Fat is not observed in the gland of young 2-month-old rats (Fig. 2).

At the electron microscope level, the structural integrity is maintained even in the acinar cells of gland from 30-month-old rats (Fig. 4). As in young rats, parallel arrays of endoplasmic reticulum are located at the basal portion of the cell while secretory granules are present in the apical cytoplasm. Golgi complexes are scattered in the cytoplasm near the nucleus. Unlike the findings in the gland of young rats, however, a large number of lipofuscin granules are present in the acinar cells of older rats. Lipofuscin granules are detected even in cells of 12-month-old rats and appear to increase in amount with increasing age.

In the radioautographs of the gland slices incubated with ${ }^{3} \mathrm{H}$-leucine, cells with radioactive grains are distributed similarly in all age groups. Cells with label are mostly localized at the periphery of the slices and even in 24-month-old rats (Fig. 5), all cells in this region are labelled uniformly. 


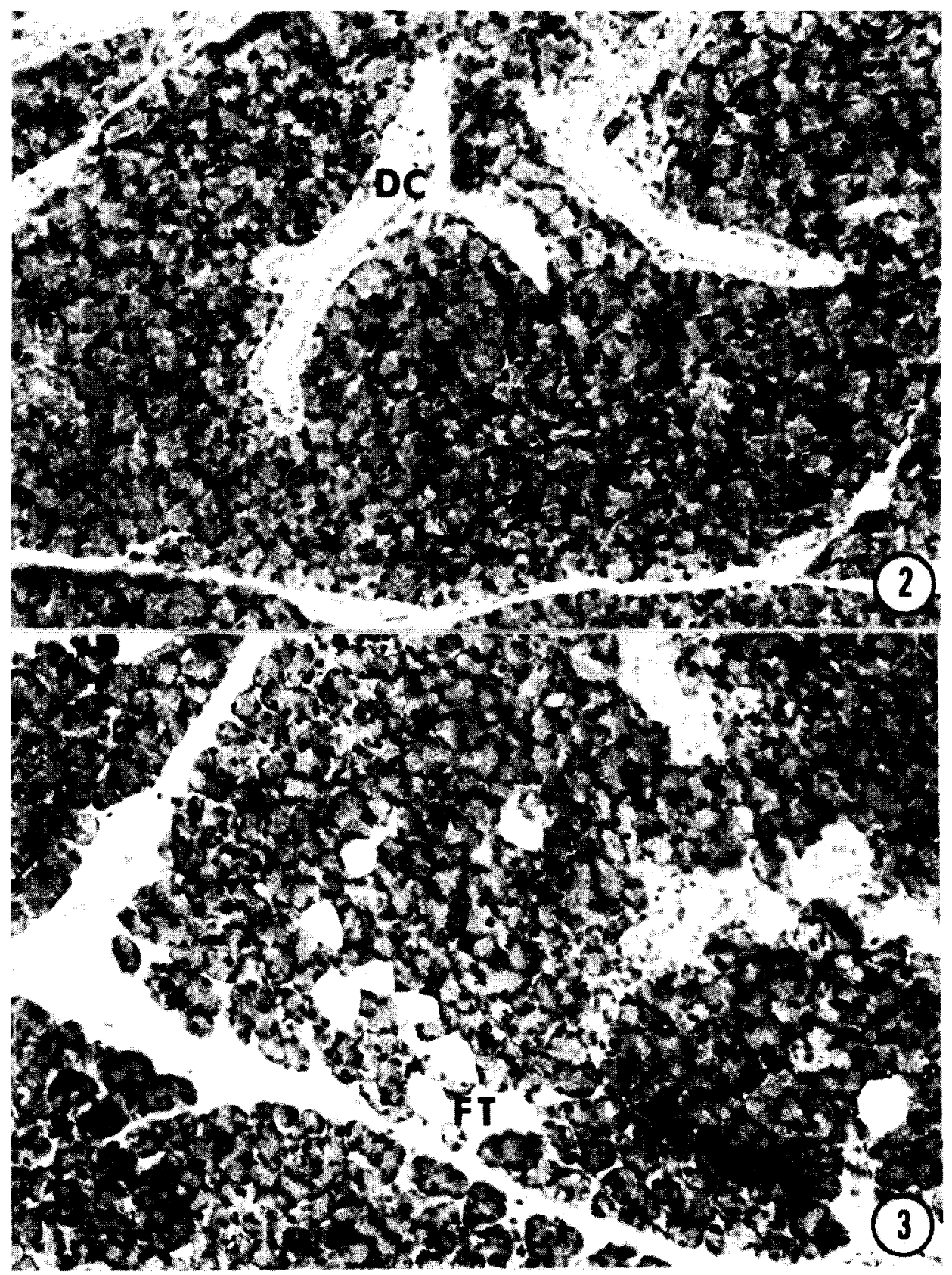

FIG 2. Light micrograph of the parotid gland from a 2-month-old rat, illustrating the structure of the gland in young rats. The gland is divided into lobules which consist of secretory acinar cells and centrally located ducts $(\mathrm{DC}) . \times 200$.

FIC. 3. Light micrograph of the parotid gland from a 30-month-old rat. The structure of the gland in this old rat is similar to that shown in Fig. 2, except for the presence of fatty tissue $(F T) . \times 200$. 


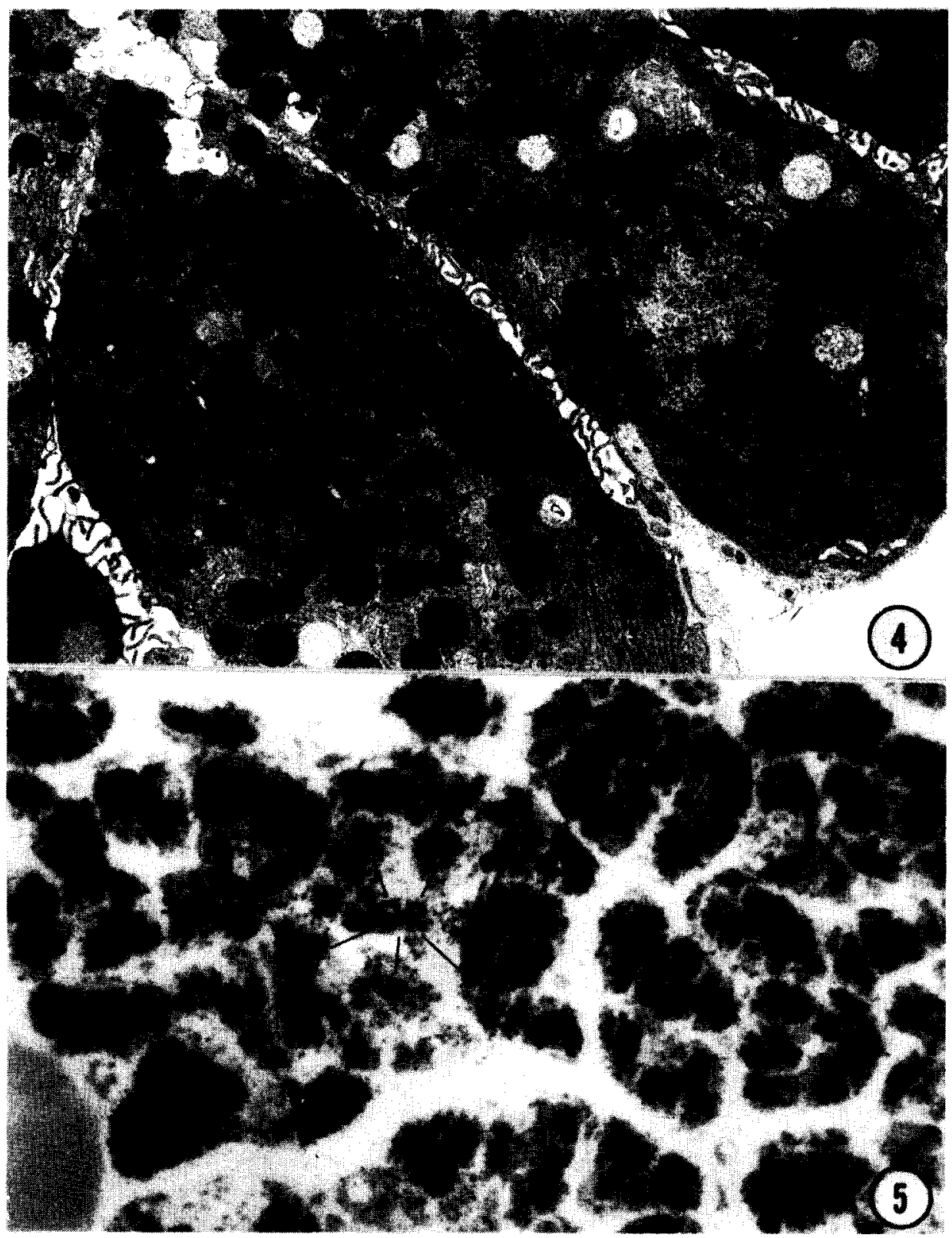

FIG. 4. Electron micrograph of the secretory acinar cells in the gland of a 30-month-old rat. As in the gland of young rats, the acinar cells contain numerous secretory granules and reveal parallel arrays of rough endoplasmic reticulum (ER) in the basal cytoplasm. Lipofuscin granules (LG) present in these cells are not detected in the gland of young rats. $\times 6500$.

FiG. 5. Radioautograph of the gland slices from a 24 -month-old rat incubated with ${ }^{3} \mathrm{H}$-leucine showing the presence of radioactive grains (GR) in most of the cells in the field. $\times 400$. 


\section{DISCUSSION}

Comparisons of the incorporation data among age groups in this study have been made based on the DNA content of the gland rather than the wet tissue weight or the total protein content. The use of wet tissue weight as the index was avoided since the weight could fluctuate depending on hydration or any age-related changes in the amount of nonsecretory tissues, such as fat or fibrous connective tissue. The use of total protein index was also avoided since this would fluctuate depending on the content of exportable secretory proteins which amount to about $50 \%$ of total cellular proteins in young rats (Schramm, 1968).

The differences in the level of ${ }^{3} \mathrm{H}$-leucine incorporated into PCA-insoluble proteins among age groups indicate that the cellular protein synthesis declines progressively with increasing age in the rat parotid gland. This decline does not appear to be related to the changes in the size of the free leucine pool, as radioactivity in the PCA-soluble fraction does not change significantly with age. The decrease in the level of radioactivity in PCA-insoluble proteins is not due to the increase in the number of non-secretory cells, as there is no obvious change in the proportion of ductal to secretory cells or in the cellularity of the connective tissue. Furthermore, in the radioautographs of the incubated glands, the grains are fairly uniformly distributed among secretory cells, suggesting that the decreased level of radioactivity is not due to a reduction in the number of cells capable of incorporating the label.

The reduced level of radioactivity in PCA-insoluble proteins following the incubation of the gland slices with $\left[\mathrm{U}-{ }^{H} \mathrm{C}\right]-\mathrm{D}$-glucose in older rats further supports the hypothesis that protein synthesis declines with aging. Furthermore, the incorporation of radioactivity into total lipids by the same gland slices does not change with age, indicating that the decline in the synthesis of proteins is a specific change which affects only this process and not the overall synthetic activity of the cells. In addition, the ability of cells to oxidize ${ }^{1+} \mathrm{C}$-glucose to ${ }^{14} \mathrm{CO}_{2}$ is unchanged or even somewhat elevated in older animals. This also indicates that the decline in protein synthesis is not a reflection of a general decline in cellular metabolism.

The results from this study are consistent with the findings of many previous studies. Previous studies of amino acid incorporation in vitro have shown that many different types of tissues from older animals are less active in protein synthesis than those from younger animals (Brever and Florini, 1965; Murthy, 1966; Hrachovec, 1969; Mainwaring, 1969; Srivastava, 1969; Buetow and Gandhi, 1973; Connolli, 1973; Britton and Sherman, 1975; Kurtz, 1975; Comolli et al., 1976). Some of these studies have suggested that the inhibitory substance present in the cytosol is responsible for reduced protein synthesis (Murthy, 1966; Hrachovec, 1969; Buetow and Gandhi, 1973; Comolli, 1973; Comolli et al., 1976): However, many other studies indicate that age-related changes occur in ribosomes (Mainwaring, 1969; Wallach and Gershon, 1974; Layman et al., 1976). More recently, it has been shown that the age-related decrease in the synthetic capacity of ribosomes is due to a reduction in number of active ribosomes rather than a reduced efficiency in individual ribosomes (Kurtz, 1978).

Whether or not ribosomes of the secretory acinar cells in the rat parotid gland become inefficient in carrying out the process of translation remains to be studied. However, it appears that age-related changes which reduce the cellular efficiency in protein synthesis occur in these cells.

Some of the reported changes in the function of salivary glands in humans with advancing 
age might be related to the decline of protein synthesis in these glands. The rate of salivary flow is reduced in elderly persons (Meyer and Necheles, 1940; Bertram, 1967) and basal (fasting) as well as stimulated (chewing) secretion of saliva decreases considerably in older persons (60-90 years old) as compared to younger persons (12-60 years old). Furthermore, it appears that there is a reduction in the enzyme content of the saliva: a reduction in the content of ptyalin (Meyer et al., 1937) and amylase (Meyer and Necheles, 1940; Chilla et al., 1974) in mixed saliva has been reported in older individuals.

It has been reported that the parotid gland undergoes fatty degeneration which destroys the secretory acini and cells in old (700-day-old and older) rats of the Wistar strain (Andrew, 1949). Such destructive changes have not been observed even in the 30 -month-old rats used in this study. Fatty tissue occurs in the glands of the rats used and appears to increase in amount with age. However, the fat is located mostly in the connective tissue septa or at the periphery of the lobules. This discrepancy could be due to the difference in the strain of rats used in these two studies.

Lipofuscin granules have been observed in the glands of 12-month-old and older rats in this study, as has been reported to occur in the rat submandibular gland (Bogart, 1970) and other aging tissues (Reichel, 1968). However, whether or not lipofuscin granules affect the cellular protein synthesis, or any other aspects of cell function, remains unknown.

\section{SUMMARY}

This study was undertaken to determine whether protein synthesis declines with age in parotid salivary glands. We have examined the level of incorporation of $\left[{ }^{3} \mathrm{H}\right]$-leucine into protein and the metabolism of $\left[\mathrm{U}-{ }^{1+} \mathrm{C}\right]-\mathrm{D}$-glucose in 2-, 12-, 18-, 24- and 30-monthold rats. The rate of incorporation of $\left[{ }^{3} \mathrm{H}\right]$-leucine into perchloric acid insoluble protein by gland slices decreases progressively with age from $138.43 \pm 5.43 \mathrm{nmole} / \mathrm{mg} \mathrm{DNA} / \mathrm{h}$ at 2 months to $109.77 \pm 6.88,97 \pm 4.68,71.62 \pm 4.13$ and $58.08 \pm 5.61 \mathrm{nmole} / \mathrm{mg} \mathrm{DNA} / \mathrm{h}$ at $12,18,24$ and 30 months, respectively. The amount of radioactivity in the perchloric acid soluble fraction remains relatively stable at all ages. The ability of gland slices to oxidize [U- $\left.{ }^{1+} \mathrm{C}\right]$-D-glucose to ${ }^{1+} \mathrm{CO}_{2}$ and to incorporate radioactivity into the total lipid does not change with age, whereas the incorporation of radioactivity into protein decreases significantly from $45.06 \pm 3.55$ at 2 months to $21.75 \pm 1.30 \mathrm{nmoles}$ glucose $/ \mathrm{mg}$ $\mathrm{DNA} / \mathrm{h}$ at 24 months. Histologically, no significant change is detected in the proportion of secretory cells to ductal cells in the different age groups. In radioautographs of the glands incubated with $\left[{ }^{3} \mathrm{H}\right]$-leucine, the distribution of cells with grains is similar in all age groups. Lipid droplets occur at the periphery of the lobules and a large number of lipofuscin granules are present in secretory acinar cells of 12-month-old and older rats when viewed in the electron microscope. However, the structural integrity in the cellular organelles is maintained in the acinar cells of all age groups. These results indicate that the ability of parotid gland cells to synthesize protein decreases with age. The decrease reflects specific changes in protein synthesis and not an overall decline in cellular metabolism or a decrease in the number of cells which incorporate leucine.

Acknowledgements - The authors thank Virginia Hartog for carrying out the tissue preparations for microscopy. The work was supported by the Veterans Administration and by grant AG00944 from the National Institute of Health. 


\section{REFERENCES}

ANDREW, W. (1949) Am. J. Anat. 85, 157.

Beauchene, R. E. Roeder, L. M. and Barrows, C. H. (1970) J. Geront. 25, 359.

Bertram, U. (1967) Acta odont. scand. 25, Suppl. 49, 1.

Bogart, B. I. (1970) J. Morph. 130, 337.

Brever, C. B., Davies, M. C. and Florini, J. R. (1964) Biochemistry (Wash.) 3, 1713.

BREVER, C. B. and FLORINI, J. R. (1965) Biochemistry 4, 1544.

Britton, G. W. and Sherman, F. G. (1975) Exp. Geront. 10, 67.

Buetow, D. E. and Gandhl, P. S. (1973) Exp. Geront. 8. 243.

BURTON, K. (1956) Biochem. J. 62, 315.

Castle, J. D., Jamieson, J. D. and Palade, G. E. (1972) J. Cell Biol. 53, 290.

Chen, J. C., Ove, P. and LANSING, A. I. (1973) Biochim. biophys. Acta. 312, 598.

Chilla, R., Niemann, H., Arglebe, C. and Domagk, G. F. (1974) ORL 36, 372.

COMOLLI, R. (1973) Exp. Geront. 8, 307.

Comolli, R., Delpiano, C. and Shubert, A. C. (1976) Exp. Geront. 11, 5.

Folch, J., LeEs, M. and Sloane Stanley, G. H. (1957) J. biol. Chem. 226, 497.

Hinrichs, H. R., Petersen, R. O. and BASERGA, R. (1964) Archs Path. 78, 245.

Hrachovec, J. P. (1969) Gerontologia 15, 52.

JoHNSON, T. C. (1968) J. Neurochem. 15, 1189.

Johnson, T. C. and Belytschko, G. (1969) Proc. nat. Acad. Sci. 62, 844.

KIM, S. K. (1976) J, supramol. Struct. 4, 185.

KLETHI, J. (1976) Invest. Ophthal. 15, 430.

KurTz, D. I. (1975) Biochim. biophys. Acta. 407, 479.

KURTZ, D. I. (1978) Exp. Geront. 13, 397.

Layman, D. K., RicCA, G. A. and Richardson, A. (1976) Archs Biochem. Biophys. 173, 246.

LiU, D. S. H., Ekstrom, R., Spicer, J. W. and Richardson, A. (1978) Exp. Geront. 13, 197.

MAINWARING, W. I. (1968) Biochem. J. 110, 79.

MAINWARING, W. I. (1969) Biochem. J. 113, 869.

Meyer, J. Golden, J. S. Steiner, N. and Necheles, H. (1937) Am. J. Physiol. 119, 600.

MeYer, J. and NeCheles, H. (1940) J. Am. med. Ass. 115, 2050.

MURTHY, M. R. V. (1966) Biochim. biophys. Acta. 119, 599.

MURTHY, M. R. and RAPPOPORT, D. A. (1965) Biochim. biophys. Acta. 95, 121.

ReICHEL, W. (1968) J. Geront. 23, 145.

Schramm, M. (1968) Biochim. biophys. Acta. 165, 546.

SRivastava, U. (1969) Archs Biochem. Biophys. 130, 129.

Wallach, Z. and Gershon, D. (1974) Mech. Age. Dev. 3, 225. 